\title{
THE BODY IN JESUS' TOMB AS A HYLEMORPHIC PUZZLE: A RESPONSE TO JAEGER AND SIENKIEWICZ AND AN APPLICATION FOR CHRISTOLOGICAL ANTHROPOLOGY
}

\author{
JAMES T. TURNER, JR.*
}

Anderson University

\begin{abstract}
In a recent paper, Andrew Jaeger and Jeremy Sienkiewicz attempt to provide an answer consistent with Thomistic hylemorphism for the following question: what was the ontological status of Christ's dead body? Answering this question has christological anthropological import: whatever one says about Christ's dead body, has implications for what one can say about any human's dead body. Jaeger and Sienkiewicz answer the question this way: that Jesus' corpse was prime matter lacking a substantial form; that it was existing form-less matter. I argue that their argument for this answer is unsound. I say, given Thomistic hylemorphism, there was no human body in Jesus's tomb between his death and resurrection. Once I show their argument to be unsound, I provide a christological anthropological upshot: since there was no human body in Christ's tomb, there are no human bodies in any tomb.
\end{abstract}

KEYWORDS: Jaeger; Philosophical Anthropology; Christological Anthropology; Aquinas

\section{Introduction}

Typically, given a Thomistic (even broadly Thomistic) hylemorphic metaphysics, a corpse, if it is a substance at all, is not the numerically same substance as the living body from which the matter of the corpse comes. For Christian theologians and philosophers, this creates a potential worry. This is because, according to the creeds, Christ was buried. And this does not seem correct on a hylemorphic account-prima facie, anyway-since ex hypothesi, on hylemorphism, the human Christ is wherever his body is. If his body is not in the tomb, neither is he. So, Christ was not buried. Christians reject this conclusion; yet, on a hylemorphic account, it is not obvious how to reject it since there is an important unanswered question: what is the ontological status of Christ's dead body (Wippel 2011: 150ff; Jaeger and Sienkiewicz 2018: 132)? In their 2018 work, Andrew Jaeger and Jeremy Sienkiewicz attempt to provide an answer for this. They argue that Jesus' corpse was prime matter

* James T. Turner, JR. (PhD 2015, University of Edinburgh) is Assistant Professor of Philosophy at Anderson University in South Carolina, USA. He can be contacted by email atJTurner@andersonuniversity.edu. 
lacking a substantial form; that it was existing form-less matter (Jaeger and Sienkiewicz 2018: 131-145). They make clear that their aim is not to provide an account of whose body it is; that much they take for granted, viz., that it is the body of Christ. They seem to be following Aquinas here who defends the proposition that whatever the body is that is in the tomb, it is hypostatically united to the Person of Christ (i.e., the Word) and so remains the body of Christ. See (Aquinas 1981b: III.Q50.a2). Jaeger and Sienkiewicz suggest that, during the time between Jesus' death and resurrection, God acted as a metaphysical 'stand-in' for Jesus' body's formal cause; that is, that, by miracle, God did the work that Jesus' soul, under normal conditions, would do, viz., keep in act the prime matter of Jesus' body. In so doing, they suggest that the following thesis is compatible with hylemorphic metaphysics, perhaps even to a Thomistic variety if Thomas's view were properly amended: that God upholds the existence of Jesus' corpse as un-formed prime matter (Jaeger and Sienkiewicz 2018: 133-134). I call this the Un-Formed ${ }_{M}$ Thesis. [Note that the claim that Christ is wherever his body is is consistent with the traditional Thomistic claim that the Person of the Word was, qua human, both in the tomb by hypostatic union with his body and in Limbus Patrum by hypostatic union with his human soul during the time between his death and resurrection. Aquinas deals with this worry specifically in his 1981b: III.Q50.a2 and a5. See also Wippel 2011: 150 and Jaeger and Sienkiewicz 2018: 131. For an argument that problematizes the location of the human Jesus during Holy Saturday vis-à-vis hylemorphism, see Turner 2021: 1-16.]

In this paper, I provide a different conclusion to the important unanswered question at issue. What is the ontological status of Christ's dead body? My answer is that Christ's dead body has no ontological status; for there is no body in Jesus' tomb between his death and resurrection. I argue this by way of reply to Jaeger and Sienkiewicz's daring Un-Formed ${ }_{M}$ thesis. So, after a brief summary of Jaeger and Sienkiewicz's position, my argument proceeds in two steps. Step 1: in section II, I argue that the main argument for UnFormed $_{\mathrm{M}}$ rests on a mistake: the claim that prime matter is an act of a substantial form. This mistake renders their argument unsound. So, UnFormed $_{\mathrm{M}}$ should be rejected. Step 2: in Section III, I show that amending their argument in light of prime matter's being a cause not an act advances another thesis, what I call the Un-Formeds Thesis: that God could sustain the existence of a substance without its substantial form. Helpfully, for Jaeger and Sienkiewicz's purposes, if Un-Formed $\mathrm{d}_{\mathrm{S}}$ is correct, then there's another way to address the ontological status of Christ's dead body that does not rest on the mistake of thinking that prime matter is an act of substantial form. For, according to Un-Formeds, God could uphold a form-less substance, even the form-less substance of Jesus' dead body. Unfortunately, I go on to show that it turns out that there are two problems for Un-Formeds. First, it is 
metaphysically impossible. To argue for this, I flesh out the notion of an essentially ordered causal series and explain why the substantial form/prime matter causal relation in a substance (e.g., a human organism) is an essentially ordered causal series, the sort of series the causes of which are, as the name implies, essential to it. So, not even God can sustain an essentially ordered causal series without all of its causes in place. Second, a further reason to think that Un-Formed $\mathrm{S}_{\mathrm{S}}$ is false is that its truth undermines plausible hylemorphic criteria of identity for substances. In Section IV, I suggest that the conclusion of my argument brings with it a Christological anthropological upshot: given that Jesus' body was not buried in a grave, no human body is buried in a grave.

Before turning to my own argument, it will be helpful first to summarize Jaeger and Sienkiewicz's argument for the Un-Formed ${ }_{M}$ Thesis. So, it's to that task I now turn.

\section{The Un-Formed ${ }_{M}$ Thesis}

On a Thomistic version of hylemorphism, what causes prime matter-a metaphysical cause that is, in itself, purely potential-actually to exist is a substantial form. Substantial form is the metaphysical cause of a thing that explains why that thing exists and is actually the thing it is rather than something else. Prime matter and substantial form act as metaphysical complements; they each are causes essential to the explanation and existence of individual substances. If there's one central thesis in Thomistic hylemorphism, it is this: there is no matter without form and no form without matter. The only matter that exists actually is formed matter. [This sort of matter is variously called signate matter, sensible matter, and/or secondary matter. Prime matter exists potentially, not actually. Aquinas spells this out in, among other places, Aquinas 2015: 206. For a helpful and pellucid overview in the secondary literature, see Feser 2014: 164-175; Wippel 2000: 296ff; Oderberg 2007: 71 76.]

On this way of cutting reality at its joints, individual objects are actualized/formed matter. They are things that potentially were the case and now actually are the case. What explains the move from potency to act, on a hylemorphic model, is matter and form. In the realm of created reality, what things are real in the truest and most plain sense are substances, individual concrete objects that exist in their own right. Substances, on this way of thinking, neither are parts of other objects that exist in their own right, nor are they modifications of those objects, nor are they mere aggregations of parts. They are, in the truest sense, wholes. In the medieval vernacular, they are unum simpliciter. These are the proper bearers of accidents and properties generally. What explains this deep-seated unity-what, for the hylemorphist makes an object a substance-is the causal relation between prime matter and 
substantial form. The utter inability for prime matter-that which is not actual in any way without a form-to exist apart from substantial form provides for the hylemorphist the metaphysics to explain why a substance genuinely is one unified thing. For, neither the substance nor any causal part of it can exist apart from the union of its substantial form and prime matter. Prizing apart the form and matter of an object destroys an object in the same way that prizing apart the triangularity from the trilaterality of a triangle destroys a triangle.

Jaeger and Sienkiewicz know all of this. Thus, they admit that the (what I call) Un-Formed ${ }_{M}$ Thesis should sound to the Thomistically-inclined hylemorphist like a 'blatant contradiction' (Jaeger and Sienkiewicz 2018: 134). John Wippel (2000) puts the contradiction-and thus Thomas's aversion to anything like Un-Formed ${ }_{\mathrm{M}}$-nicely: ' $\ldots$ if prime matter is indeed pure potentiality, as Thomas maintains, to say that it could actually exist without any form would be to say that it is in act (and therefore participates in form) and not in act (since according to the hypothesis it does not participate in form) at one and the same time' (325). Even still, Jaeger and Sienkiewicz wish to advance their thesis and propose it as one amenable to a Thomistic ontology.

There seem to be good reasons to do this; after all, how one conceives of the ontological status of Christ's dead body might undermine central Thomistic hylemorphic theses: among them are the unity of substantial form (i.e., that each substance has only one substantial form) and that substantial change entails numerical change (see Wippel 2011: 134ff). Whatever else Jaeger and Sienkiewicz wish to say about the ontological status of Christ's dead body, they wish to say that their thesis is consistent with the claim that human bodies have only one substantial form and that no new substantial form replaces Jesus' human form in his dead body (2018: 134, 141-144). For, so the Thomistic hylemorphist might suggest, if one supposes that there is more than one substantial form in a substance, then the unity of the substance is called into question. Further still, if Christ's human form were replaced by another substantial form, then the numerical identity between the pre-mortem and post-mortem body of Christ would be destroyed; for a substantial change will have taken place. Protecting these two theses and that Jesus' body is in the tomb becomes more difficult when faced with what is, for the hylemorphist, a given: Jesus' human form is not in the tomb. [Thomas, for example, thinks that Christ's human form—his soul—went to Limbus Patrum between his death and resurrection (1981b: III.Q52.a3 respondeo).]

What is more, according to contemporary Thomistic scholarship, Thomas never addresses how to make sense of the ontological status of the body in the tomb (Wippel 2011: 153-154). He does address the relation of the body in the tomb (whatever its ontological status) to the Person of Christ; that is, 
he explains how it remains united hypostatically to the Word. But he never explains how there's a body there to begin with, which is particularly vexing because apparently there's no form present in Jesus' tomb. Jaeger and Sienkiewicz, then, rightly see that there's a hylemorphic puzzle to figure out: how does form-less matter exist as a body, viz., the body in Jesus' tomb?

To answer this question, Jaeger and Sienkiewicz construct the following argument:

(1) God is able to produce all acts of secondary causes without those secondary causes. (premise)

(2) Substantial forms are secondary causes of the actuality of prime matter. (premise)

(3) Therefore, God is able to cause the actuality of prime matter without substantial forms. (from 1 and 2)

(4) If God is able to cause the actuality of prime matter without substantial forms, then it is metaphysically possible for prime matter to exist without substantial forms. (premise)

(5) Therefore, it is metaphysically possible for prime matter to exist in actuality without substantial forms. (from 3 and 4) [Argument taken verbatim from Jaeger and Sienkiewicz 2018: 134-135.]

If their argument is sound, then there's an easy remedy to the hylemorphic puzzle: God sustains the form-less matter in Jesus' tomb. I think one should grant premises (4) and (5) given premises (1)-(3). And, since (3) just follows from (1) and (2), premise (3) is sheltered under the truth of (1) and (2). On cue, much of their defense of the argument centers on premises (1) and (2).

Their defense of premises (1) and (2) is straightforward. They suggest, with good reason, that much of the Christian hylemorphic tradition is committed to their truth. Aquinas, for example, seems explicitly to say that God is able to produce all the acts of secondary causes without those secondary causes (i.e., that premise (1) is true). For the hylemorphist, causality is understood in terms of ontological dependence, not in terms of a Humean before/after sort of series. For the hylemorphic theist, since God is omnipotent and that on which everything is ontologically dependent, God can continue to uphold the existence of things without any intermediary causes. Jaeger and Sienkiewicz spell this out in the following principle:

The Omnipotent Principle ( $\left.O P^{*}\right)$ : If effect E's dependence on secondary cause C itself depends on God, then it is possible for effect $\mathrm{E}$ to depend on God without $\mathrm{E}$ depending on C (Jaeger and Sienkiewicz 2018: 136. Italics in the original).

With $\left(\mathrm{OP}^{*}\right)$, they reason that premise $(1)$ is true. The claim is that the actuality of prime matter is an effect $\mathrm{E}$ that depends on a secondary cause, viz., a substantial form, which itself depends on God. Thus, since God can produce any 
effect that a secondary cause can, God can produce the actuality of prime matter without an intermediate secondary cause (i.e., without substantial form). [That God is able to produce all the acts of secondary causes without those secondary causes comes clearly to the fore especially in Thomas's defense of how the accidents of bread and wine remain in the Eucharist. See 1981c: III.Q75.A5.ad1.]

Premise (2) also seems to be true, given hylemorphism as it has been understood in the Christian tradition. Anyone familiar with Thomas's various versions of the cosmological argument will know that, according to Thomas, there's only one first cause: God. Secondary causes are all other causes intermediate and dependent for their causality on God, the uncaused first cause. With the defense of the first two premises in place, Jaeger and Sienkiewicz

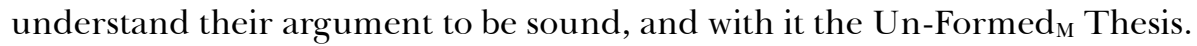
[They do defend each of the premises, of course, see Jaeger and Sienkiewicz (2018: 139); but they recognize that the one's really at issue are premises (1) and (2). I agree.]

Yet, it is the case that, despite what seems like a standard agreement among hylemorphists in the Christian tradition that (1) and (2) are true, standard bearers-like Thomas-take it to be false that even God could sustain the existence of form-less prime matter (Aquinas 1981a: I.Q66.A1 sed contra; Wippel 2000: 324-325; Brower 2014: 19). Thomas et. al. take it to be false that even God could sustain the existence of an entity that is purely potential (i.e., not actual) without its metaphysical complement, the cause by which a thing is brought from potentiality to actuality, namely substantial form. I think Aquinas and others are correct and that Un-Formed ${ }_{M}$ is false. In the next section I begin to show why: Jaeger and Sienkiewicz's argument rests on a mistake. [It should be noted that apparently some of Thomas's interlocutors thought it possible that God could sustain the existence of formless prime matter, e.g., Henry of Ghent, John Duns Scotus, and William of Ockham. See Wippel 2000: 324-325; Brower 2014: 120-121.]

\section{Prime Matter Is Not an Act}

We have seen already that Thomas Aquinas takes the form-less existence of prime matter to be a blatant contradiction: it ascribes actuality to a non-actual entity without its cause of actuality, viz., its form. To my mind, that should alert the hylemorphist to think that there's more to Jaeger and Sienkiewicz's first premise, and Thomas's seeming advocacy for such a premise, than meets the eye. To be fair to Jaeger and Sienkiewicz, they agree that (1)'s truth is not obviously connected to the existence of form-less prime matter, that is, 'obvious' given the kinds of theistic hylemorphic commitments previously mentioned. To connect the truth of (1) to God's maintaining the existence of formless prime matter, they hang much on the Roman Catholic dogma of 
transubstantiation. They reason, with Thomas et. al., that the continued existence of the accidents of the bread and wine in the Eucharist, despite the lack of subjects (their respective matter) in which to inhere, demonstrates that God can and does perform the actions of some secondary causes. Under normal conditions, the substances of the bread and wine are the respective matter for the forms of the bread and wine accidents. After their consecration, however, God fills in for the causal activity of the (now missing) material causes in the form/matter relations, since, ex hypothesi, the substances of the bread and wine no longer are present (Aquinas 1981c: III.Q75.A5; Jaeger and Sienkiewicz 2018: 136).

Without jumping headlong into the murky metaphysics of transubstantiation, I want briefly to mention that Thomas anticipates Jaeger and Sienkiewicz's argument on this score. In anticipation, he offers a potentially salient insight: there seems to be an important difference between the continued existence of a form-a thing that is a principle of act/existence-denuded of matter, and the continued existence of that which is a principle of potency, deformed of its principle of act/existence (Aquinas 1981a: I.Q66.A1.ad3). Thomas is, after all, committed to the seemingly obvious claim that whatever continues to act, continues to exist (Aquinas 1981a: I.Q89.A1 sed contra). This is his principal reason for thinking that God is not performing the metaphysically impossible when God upholds the existence of a disembodied human form (i.e., a human soul) in the intermediate state; Aquinas claims that the human form has an act of existence not dependent on a material cause (Aquinas 1981a: I.Q89.A1 sed contra and respondeo; see also Feser 2014: 163-164). Mutatis mutandis, one could make the case that, like a disembodied human soul, the accidents of the bread and wine have acts not dependent on material causes. But the same sort of reasoning cannot be applied to prime matter, since prime matter has no act of existence in itself; it exists/acts only insofar as it is the material cause of a form/matter composite, a substance, that exists/acts. [To my knowledge, Aquinas does not make the move I have suggested above.]

There is an additional, and perhaps clearer, reason for thinking that prime matter cannot exist without a substantial form. To see it, recall Jaeger and Sienkiewicz's The Omnipotent Principle:

$\left(\mathrm{OP}^{*}\right)$ : If effect E's dependence on secondary cause $\mathrm{C}$ itself depends on God, then it is possible for effect $\mathrm{E}$ to depend on God without $\mathrm{E}$ depending on $\mathrm{C}$.

For my purposes, (OP*)'s explication raises an important question: on hylemorphism, what is an effect? Briefly, it is the result of the four Aristotelian causes: efficient, material, formal, and final. Now, there is a further question: 
is prime matter an effect? The answer to this question is: no. Prime matter is a cause; more specifically, it is a material cause. So, $\left(\mathrm{OP}^{*}\right)$ is irrelevant for a defense of prime matter's form-less existence. What is an effect is a substance, a causal explanation of which is prime matter. Note too that this should cause a re-evaluation of Jaeger and Sienkiewicz's premise (2): Substantial forms are secondary causes of the actuality of prime matter. Given that prime matter is neither an effect nor an act, the phrase 'the actuality of prime matter' should be understood as another way of saying: the substance. Understood in this way, one realizes that (2), and the hylemorphist's endorsement thereof, means that substantial forms are secondary causes of substances, not prime matter (since nothing causes prime matter; it is a cause). If so, what follows from (1) and (2) is that God can cause substances to exist without substantial forms, not that God can sustain the existence of form-less prime matter.

This result makes the implication and consequent in (4) is false. Because of this, (5) does not follow and the argument turns out to be unsound. With this, one should now see that the Un-Formed ${ }_{M}$ Thesis is, with good reason, a non-starter. But, if so, the hylemorphist is still left with a difficult question, the question Jaeger and Sienkiewicz are concerned to address: 'what is the ontological status of Christ's dead body' (Jaeger and Sienkiewicz 2018: 132)? In the next section, I will show that, with some amendment, Jaeger and Sienkiewicz's argument can be used to advance another thesis: Un-Formeds. But I will show, too, that it also is false. This will provide further reason to think that, given hylemorphism, there was no body in Jesus' tomb.

\section{Human Bodies are Essentially Ordered Causal Series}

The argument for Un-Formed ${ }_{\mathrm{M}}$ rests on an important mistake: the claim that prime matter is an act. But prime matter is not an act, it is a material cause. As such, Un-Formed $\mathrm{M}_{\mathrm{M}}$ is a non-starter. It commits a category mistake. But, as it turns out, with an important amendment to premises in Jaeger and Sienkiewicz's argument, another thesis can be advanced to explain the ontological status of the body in Jesus' tomb. To see it, let us look again to Jaeger and Sienkiewicz's original argument.

Translating phrases like 'actuality of prime matter' (and others that will be made clear presently) into 'substance', a revised form of their argument looks like this:

1. God is able to produce all acts of secondary causes without those secondary causes. (premise)

2*. Substantial forms are secondary causes of their acts, viz., their substances. (premise)

3*. Therefore, God is able to produce substances without their substantial forms. (from 1 and 2) 
4*. If God is able to produce substances without substantial forms, then it is metaphysically possible for substances to exist without substantial forms. (premise)

$5^{*}$. Therefore, it is metaphysically possible for substances to exist without substantial forms. (from $3 *$ and $4 *$ )

$\left(5^{*}\right)$ is what I call the Un-Formeds Thesis. Un-Formed s, $_{\mathrm{s}}$ if true, gives the hylemorphist a way to answer the guiding research question: what is the ontological status of the body in Jesus' tomb? The answer that Un-Formeds delivers is: it is a form-less substance.

I say that Un-Formed $\mathrm{S}_{\mathrm{S}}$ false. To understand why, we need again to think back on (OP*). Does (OP*) allow for God to produce substances without substantial forms? I understand the answer to this question to be 'no' and that $\left(3^{*}\right)$ is false. But if $\left(3^{*}\right)$ is false, then $(1),(2 *)$ or both are false. By my lights, the problem lies at least in premise (1). Here's why: the sort of acts/effects at issue in premise (1) and ( $\left.\mathrm{OP}^{*}\right)$ make sense only if the acts/effects result from an accidentally ordered causal series rather than from an essentially ordered causal series. So, (1) is false as such because it claims that God can produce all acts of secondary causes. But God cannot do this for the secondary causes in essentially ordered causal series. In other words, it is not within God's power to produce the effect of an essentially ordered causal series if the series includes secondary causes; neither is it possible for God to sustain the effect of an essentially ordered causal series if one of the effect's secondary causes ceases to exist. And, as it happens, a substance is an essentially ordered causal series.

Why can't an omnipotent God perform the acts of secondary causes in an essentially ordered causal series? The answer is that-as in the name-each cause in this sort of causal series is essential to the resulting act of the series. The resulting 'act' in the form/matter/substance causal series is the substance. To wit, Caleb Cohoe (2013) describes such causal series this way:

An essentially ordered causal series is asymmetric, irreflexive, and wholly derivative. The subsequent members in such a series are not only caused by and ontologically dependent on the preceding members, as in a transitive series, they also serve as causes only insofar as they have been caused by and are effects of all the preceding members (839-840).

What's more, a defining characteristic of such a series is that the causes are simultaneous with their effects/acts (Feser 2014: 150). So, an essentially ordered causal series is asymmetric, irreflexive, wholly derivative, and simultaneous. This means that, for an essentially ordered causal series to produce its effect, all of the series must continue to exist together. An effect of such a series only is the effect it is insofar as it has the causes that it does and insofar as they 
remain in existence with their effect/act. A classic example of this sort of series is a series the causal components of which are a hand holding a stick that's pushing a stone (Aquinas 1981a: I.Q46.A2.ad7; Feser 2014: 149ff; Kerr 2012: 545-546). Such a series is different than a so-called 'accidentally ordered causal series' in that, in an accidentally ordered series (e.g., a father begetting a son, who begets another son, and so on), the causes in question need not remain for the series to remain, and the causes need not be simultaneous with their acts. [Gavin Kerr (2012) avers that essentially ordered causal series are distinct, too, in that they are one-many causal dependency relations. Accidentally ordered series can be understood in isolated one-one relations (e.g., $x \rightarrow y$ ). But, an essentially ordered series is not this way; instead, they are, (so goes his argument) of this sort: $(\mathrm{w} \rightarrow(\mathrm{x} \rightarrow \mathrm{y}))$, such that the causal series of $\mathrm{w}, \mathrm{x}$, and $\mathrm{y}$ 'isn't constructed of isolatable units' (e.g., $(\mathrm{w} \rightarrow \mathrm{x})$ and $(\mathrm{x} \rightarrow \mathrm{y})$ ) (545). That is, to understand the series-for the series to make sense at allall causes and effects simultaneously must be accounted for. As Kerr puts it: 'Effectively a one-many causal relation is one wherein the absence of some prior cause renders the succeeding causes and effects causally inefficacious' (545). Brower (2014: 5) also concludes that, vis-à-vis the relation that matter and form bear to their substance, there's a one-many causal dependency relation. If Kerr and Brower are correct, this causal dependency relation tells us that a causal series is an essentially ordered one.]

A human body is the effect/act of an essentially ordered causal series. We can tell because a human body is simultaneous with its causes, it does not cause its causes, and is wholly derived from its causes. Since both the form and the matter, as secondary causes in an essentially ordered causal series, are essential to a human body, it follows that God cannot maintain the existence of a body without its form and prime matter. More generally, because all substances/bodies are the acts of essentially ordered causal series, it follows that God cannot sustain the existence of any substance without its form and prime-matter. As such, Un-Formeds is false. It is metaphysically impossible. [There seems even to have been some sustained medieval debate (and ambiguity in Thomas's own work) whether, for example, the form is identical to the act of the body, not just simultaneous with it (Brower 2014: 5, 68-69; Wippel 2000: 324-325). If an identity relation obtains between a form and its body's act, then it is obviously impossible to have a form's act—namely its bodyapart from its form. Jaeger and Sienkiewicz address this and, obviously, conclude that the relation is not one of identity (2018:138).]

This result is relevant because it begins to show why it is true that there is no body in Jesus' tomb. If there were a body in Jesus' tomb, then it would have a substantial form. But it does not have Jesus' substantial form. Why not? If it did, the body would be alive and not dead. Jesus' substantial form is a soul; no existing soul is dead. All embodied living souls produce living 
human bodies (Aquinas 1981a: I.Q75.A1 respondeo, I.Q77.A1 respondeo; Klima 2002: 261; Klima 2009: 164; Turner 2018: 159ff). So, if there were a body in Jesus' tomb, it would not be a human body; this is because, on this sort of hylemorphism, the only human bodies there are are living ones. Human bodies are prime matter/human soul composites. Thus, there is no human body in Jesus' tomb between his death and resurrection.

The only other option is to suggest that, at Christ's death, a new substantial form takes the place of Jesus' human soul in the left-over prime matter leaving a non-human body in the tomb. But this would be to effect a substantial change, which would make the resulting material substance numerically distinct from Jesus' body. And so, if the Person of the Word were united hypostatically to the body in Jesus' tomb, he would be hypostatically united to an entirely different object-another body, a non-human body-rather than the one human nature of Christ. It is no part of orthodox teaching to say that Christ is united to a corpse that looks like Jesus but isn't. Following this line of thinking, then, it follows that the Person of the Word is not united hypostatically to the body in Jesus' tomb. And that is because it is true that there is no body in Jesus' tomb.

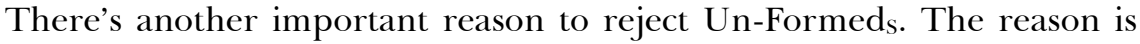
that, if we do not accept-on hylemorphism-that the human body is an essentially ordered causal series, we lose a plausible account of criteria for personal identity. Here is how: consider the following as plausible criteria of diachronic object and personal identity consistent with hylemorphism:

$\left(\mathrm{AI}_{\mathrm{T}}\right)$ : For any material substances $\mathrm{x}$ and $\mathrm{y}, \mathrm{x}$ at time, $\mathrm{T}_{1}$, is numerically identical to $y$ at time, $T_{2}$ (where $T_{2}$ is any time later than $T_{1}$ ), if and only if the substantial form of $\mathrm{x}$ at time, $\mathrm{T}_{1}$, is numerically identical to the substantial form of $\mathrm{y}$ at time, $\mathrm{T}_{2}$ (Turner 2018: $155)$.

One reason for accepting $\left(\mathrm{AI}_{\mathrm{T}}\right)$ and agreeing to its plausibility is because it gets around the anti-criterialist's complaint, viz., that all criteria of identity proposed for the persistence of objects reduce to uninformative tautologies (Merricks 1998: 106-124). Happily, $\mathrm{AI}_{\mathrm{T}}$ does not presuppose the identity of the substance the persistence of which it seeks to explain, even if it presupposes the identity of a substantial form. With my (2018: 224), I reason that is acceptable because substantial forms are not separately existing things the identities for which one must give an account (I assume without argument that the identity of forms is primitive and unanalyzable). $\left[\left(\mathrm{AI}_{\mathrm{T}}\right)\right.$ follows and amends Thomas-inspired criteria for personal identity found in (Brown 2005: 119) and (Adams 1992: 7-8). Others, including Lang (1998: 384) and Eberl (2009: 192), seem to agree that something like (what is here called) 
' $\left(\mathrm{AI}_{\mathrm{T}}\right)$ ' is the way to think of Thomas's account of criteria for personal identity. All of us are following how we read Thomas's account in, for example, Aquinas 1975: 81.6.]

Here is the relevant upshot. If one supposes that a human body-or any substance at all-is not the act of an essentially ordered causal series, then one loses the ability to explain what the persisting substance's necessary and sufficient conditions are. Consider two items from the argument laid about above:

(3*) Therefore, God is able to produce substances without their substantial forms,

and

(5*) Therefore, it is metaphysically possible for substances to exist without substantial forms.

If $\left(3^{*}\right)$ and $\left(5^{*}\right)$ were true, it would follow that a substance's substantial form is not necessary for a substance's existence. In other words, $\left(\mathrm{AI}_{\mathrm{T}}\right)$ would be false because it claims that the identity of a material object (e.g., a pre-mortem or post-resurrection human body) hangs on whether the relevant substantial form exists. But $\left(\mathrm{AI}_{\mathrm{T}}\right)$ is true (and the hylemorphist has good reason to think so). Thus, by modus tollens, $\left(3^{*}\right)$ and $\left(5^{*}\right)$-Un-Formed $—$ are (is) false.

\section{An Important Christological-Anthropological Implication}

Given a Thomistic-style hylemorphism, the Un-Formed ${ }_{\mathrm{M}}$ and Un-Formed theses are false. There is neither form-less prime matter nor form-less substance in Jesus' tomb between his death and resurrection. So, what is the ontological status of the body in Jesus' tomb? There is no body in Jesus' tomb. At least, there is no macro-sized body. By my lights, it is possible that, in the tomb, there were millions of tiny substances, what we might call 'atoms' arranged in a corpse-wise way. To speak loosely, then, there might have been some things there; but nothing that was form-less.

A fortiori, the same goes for every human vis-à-vis her buried 'body'. Why? In Christian theology, anyway, that Christ is 'the true human' carries metaphysical weight: what one says about the incarnate Christ's humanity, particularly with respect to his death and resurrection, one should say about humans generally (Cortez 2017: 36; 1 Corinthians 15:12-23). To make this sort of move is part of what it means to reason christologically about anthropology. In other words, it is part of doing christological anthropology. Marc Cortez outlines this sort of approach in two ways, what he calls 'minimal 
christological anthropology' and 'comprehensive christological anthropology'. He says:

A minimally christological anthropology is one in which (a) Christology warrants important claims about what it means to be human and (b) the scope of those claims goes beyond issues like the image of God and ethics.

A comprehensively christological anthropology is one in which (a) Christology warrants ultimate claims about true humanity such that (b) the scope of those claims applies to all anthropological data (Cortez 2017: 21).

I suggest that the conclusions of my previous arguments about the ontological status of the body in Jesus' tomb applies mutatis mutandis to all humans, if either minimal or comprehensive christological anthropology is the appropriate way to think about the human creature.

I wish not to adjudicate here which approach to christological anthropology one should take. For present purposes, it matters not which approach is correct; hence, I've placed a disjunction in the claim that our conclusions concerning the ontological status of the body in Jesus' tomb generalizes to the ontological status of the bodies in all tombs. That is: there are no human bodies in the tombs of dead human beings. Such a conclusion should be easy to see; neither of the arguments for the Unformed $_{M}$ and Unformed $_{S}$ theses require that Jesus' body be in view. Ultimately, they are unsound by virtue of the ways they reason about prime matter, substantial form, and substances in general hylemorphic terms. So, one should think of the preceding arguments as something of a test-case, wherein the concrete human nature of Christ is the exemplar analysans helping to decipher some further, more general, analysandum. And, following Cortez, if it is the case that what one says about Christ's human nature delivers either important or ultimate claims about what it means to be human, featuring Christ as a test-case is fitting. And so the sober metaphysical truths implied by undermining the arguments for Unformed $_{M}$ and Unformed U $_{S}$ that there is neither form-less prime matter nor formless material substance-can be stated in a pithy christological anthropological way: Since there was no dead human body in Jesus' tomb, there is no dead human body in anyone's tomb.

\section{Bibliography}

Adams MM (1992) The Resurrection of the Body According to Three Medieval Aristotelians: Thomas Aquinas, John Dun Scotus, William of Ockham. Philosophical Topics 20(2): 1-33.

Aquinas T (1975) Summa Contra Gentiles, volume 4, translated by O’Neil CJ. Notre Dame, IN: University of Notre Dame Press. 
Aquinas T (1981a) Summa Theologica, volume 1, translated by the Fathers of the English Dominican Province. Notre Dame, IN: Ave Maria Press.

Aquinas T (1981b) Summa Theologica, volume 4, translated by the Fathers of the English Dominican Province. Notre Dame, IN: Ave Maria Press.

Aquinas T (1981c) Summa Theologica, volume 5, translated by the Fathers of the English Dominican Province. Notre Dame, IN: Ave Maria Press.

Aquinas T (2015) On the Principles of Nature. In Shalley-Jenson M (ed) The Middle Ages (476-1500). Ipswitch: Salem Press, pp. 204-211.

Brower JE (2014) Aquinas's Ontology of the Material World: Change, Hylomorphism, and Material Objects. Oxford: Oxford University Press.

Brown C (2005) Aquinas and the Ship of Theseus. London: Continuum.

Cohoe C (2013) There Must Be a First: Why Thomas Aquinas Rejects Infinite, Essentially Ordered, Causal Series. British Journal for the History of Philosophy 21(5): 838-856.

Cortez M (2017) ReSourcing Theological Anthropology: A Constructive Account of Humanity in the Light of Christ. Grand Rapids, MI: Zondervan.

Eberl JT (2009) Do Human Persons Persist between Death and Resurrection? In Timpe K (ed) Metaphysics and God: Essays in Honor of Eleonore Stump. New York, NY: Routledge, pp. 188-205.

Feser E (2014) Scholastic Metaphysics: A Contemporary Introduction. Heusenstamm: Editiones Scholasticae.

Jaeger AJ and Sienkiewicz J (2018) Matter without Form: The Ontological Status of Christ's Dead Body. Journal of Analytic Theology 6 (2018): 131-145.

Kerr G (2012) Essentially Ordered Series Reconsidered. American Catholic Philosophical Quarterly 86(4): 541-555.

Klima G (2009) Aquinas on the Materiality of the Human Soul and the Immateriality of the Human Intellect. Philosophical Investigations 32(2): 163182.

Klima G (2002) Man = Body + Soul. In Davies B (ed) Thomas Aquinas: Contemporary Philosophical Perspectives. Oxford: Oxford University Press, pp. 257-273.

Lang DP (1998) The Thomistic Doctrine of Prime Matter. Laval Theologique et Philosophique 54(2): 367-385.

Merricks T (1998) There Are No Criteria of Identity Over Time. Nous 32(1): 106-124.

Oderberg DS (2007) Real Essentialism. London: Routledge.

Turner JT (2021) Hylemorphism, Rigid Designators, and the Disembodied 'Jesus': A Call for Clarification. Religious Studies 57(2): 1-16.

Turner JT (2018) On the Resurrection of the Dead: A New Metaphysics of Afterlife for Christian Thought. London: Routledge.

Wippel JF (2011) Thomas Aquinas and the Unity of Substantial Form. In Emery K, Friedman RL, Speer A, Mauriege M, and Brown SF (eds) 
Philosophy and Theology in the Long Middle Ages: A Tribute to Stephen F. Brown. Leiden: Brill.

Wippel JF (2000) The Metaphysical Thought of Thomas Aquinas. Washington, DC: The Catholic University of America Press. 